\title{
PEMBELAJARAN PERKALIAN PECAHAN BIASA BERBANTU MEDIA BENDA KONKRET: Studi Kasus Perbedaan Gender terhadap Kemampuan Matematika Siswa Kelas V SDN Sambiroto 3 Semarang
}

\author{
Kristi Liani Purwanti \\ Universitas Islam Negeri (UIN) Walisongo Semarang \\ e-mail: kristilianipurwali@walisongo.ac.id
}

\begin{abstract}
Abstrak
Pembelajaran operasi kali dua pecahan di sekolah dasar masih menggunakan cara instan. Pembelajaran dengan cara tidak menggenal konsep dasar matematika, teringatnya tidak akan lama dibandingan menggunakan media pembelajaran. Didalam pembelajaran juga berdasarkan teori belajamya Bruner yang bisa digunakan dalam pembelajaran perkalian pecahan. Anak diajak menemukan secara langsung konsep perkaliannya. Media yang digunakan hanya selembar kertas HVS, ini merupakan tahap enaktif dari teori belajaran Bruner. Setelah anak mulai mengerti bagaimana membuat perkalian pecahan dengan kertas HVS, dilanjutkan dengan menggambar pada kertas berpetak, ini merupakan tahap ikonik di dalam teori belajar Bruner. Terakhir tahap simbolik anak menggunakan simbol secara langsung tentang perkalian pecahan. Pembelajaran ini diterapkan pada anak kelas 5 di SDN Sambiroto Tembalang Semarang dapat meningkatkan hasil pemahaman anak perempuan dan anak laki-laki terhadap perkalian pecahan. Kemampuan anak laki-laki dan perempuan tidak ada perbedaan. Hasil evaluasi sama, saat proses berbeda ada kecenderungan anak perempuan lebih cepat menguasi dibandingkan anak laki-laki.
\end{abstract}

Kata Kunci: perkalian pecahan; pemahaman Matematika; media benda konkret

\section{A. Pendahuluan}

Tujuan utama guru pada pembelajaran matematika adalah menolong peserta didik untuk memahami matematika dan mendorong mereka menggunakan matematika untuk menyelesaikan masalah dalam kehidupan sehari-hari serta menikmati pembelajaran matematika. Pembelajaran matematika adalah proses pemberian pengalaman belajar kepada siswa 
melalui serangkaian kegiatan yang terencana sehingga siswa memperoleh kompetensi tentang bahan matematika yang dipelajari. ${ }^{1}$

Pembelajaran perkalian pecahan biasa merupakan materi yang gampang-gampang susah sebab biasanya guru mengajarkannya dengan cara langsung tanpa bantuan media serta dikenalkan tanpa mengenal konsep dasar. Jika siswa tidak mengenal konsep dasarnya, anak akan lebih cepat pula melupakan materi yang dipelajarinya. Setiap pembelajaran perkalian pecahan tidak ada guru yang menggunakan media. Untuk membantu siswa kelas 4 SDN Sambiroto 3 Semarang untuk menemukan konsep perkalian pecahan biasa maka dianjurkan menggunakan media benda konkret agar kemampuan Matematika anak meningkat.

\section{B. Pembelajaran}

Dalam keseluruhan proses pendidikan di sekolah, pembelajaran merupakan aktivitas yang paling utama. Ini berarti bahwa keberhasilan pencapaian tujuan pendidikan banyak bergantung pada bagaimana proses pembelajaran dapat berlangsung secara efektif. Pemahaman seorang guru terhadap pengertian pembelajaran akan sangat mempengaruhi cara guru itu mengajar. Menurut Gagne dan Riggs ${ }^{2}$ mengatakan pembelajaran adalah suatu sistem yang bertujuan untuk membantu proses belajar siswa, yang berisi serangkaian peristiwa yang dirancang, disusun sedemikian rupa untuk mempengaruhi dan mendukung terjadinya proses belajar siswa yang bersifat internal. Jadi, inti pembelajaran adalah segala upaya yang dilakukan oleh guru agar terjadi proses belajar pada diri anak didik.

Dari pendapat-pendapat di atas dapat disimpulkan bahwa pembelajaran adalah proses interaksi peserta didik dengan pendidik dan sumber belajar yang dilakukan dengan sengaja sehingga memungkinkan peserta didik belajar untuk melakukan atau mempertunjukkan tingkah laku tertentu pula.

Matematika merupakan suatu bahan kajian yang memiliki objek abstrak dan dibangun melalaui proses penalaran deduktif, yaitu kebenaran sebelumnya sehingga keterkaitan antar konsep dalam Matematika bersifat

\footnotetext{
${ }^{1}$ Muhsetyo, Gatot, Pembelajaran Matematika SD, (Jakarta: Universitas Terbuka, 2009), h. 9

${ }^{2}$ Djamarah, Syaiful Bahri dan Zain, Aswan. Strategi Belajar Mengajar, Jakarta: Asdi Mahasatya, 2010.), h. 325.
} 
sangat kuat dan jelas. Matematika berfungsi untuk mengembangkan kemampuan bernalar melalui kegiatan penyelidikan, eksplorasi, dan eksperimen, sebagai alat pemecahan masalah melalui pola berfikir dan model Matematika, serta sebagai alat komunikasi sebagai simbol, tabel, grafik, diagram, dalam menjelaskan gagasan. ${ }^{3}$

Menurut Karso pembelajaran Matematika di SD mempunyai ciri-ciri sebagai berikut: ${ }^{4}$

\section{Pembelajaran Matematika menggunakan metode spiral.}

Pendekatan spiral dalam pembelajaran matematika merupakan pendekatan dimana pembelajaran konsep atau suatu topik matematika selalu mengkaitkan atau menghubungkan dengan topik sebelumnya. Topik sebelumnya dapat menjadi prasyarat untuk dapat memahami dan mempelajari suatu topik matematika. Topik baru yang dipelajari merupakan pendalaman dan perluasan dari topik sebelumnya.

Pemberian konsep dimulai dengan benda-benda konkret kemudian konsep itu diajarkan kembali dengan bentuk pemahaman yang lebih abstrak dengan menggunakan notasi yang lebih umum digunakan dalam Matematika.

\section{Pembelajaran Matematika bertahap}

Materi pelajaran Matematika diajarkan secara bertahap yaitu dimulai dari konsep-konsep yang sederhana, menuju konsep yang lebih sulit. Selain itu pembelajaran Matematika dimulai dari yang konkret, ke semi konkret dan akhirnya kepada konsep abstrak. Untuk mempermudah siswa memahami objek Matematika maka benda-benda. konkret digunakan pada tahap konkret, kemudian ke gambar-gambar pada tahap semi konkret dan akhirnya ke simbol-simbol pada tahap abstrak.

Sedangkan tujuan pembelajaran Matematika menurut Karso ${ }^{5}$ adalah melatih dan menumbuhkan cara berfikir secara sistematis, logis, kritis kreatif

3Karim, Pendidikan Matematika 2, (Jakarta: Universitas Terbuka, 2014), h. 37.

4Karso, Pendidikan Matematika 1, (Jakarta: Universitas Terbuka, 2014), h. .43

5Ibid., h. 62. 
dan konsisten. Juga mengembangkan sikap gigih dan percaya diri dalam menyelesaikan masalah.

Teori belajar yang mendasari metode inkuiri, menurut Sanjaya (2011: 196) adalah teori belajar konstruktivism. Konstruktivisme adalah sebuah teori yang memaparkan bahwa, manusia membangun atau mengkonstruksi pengetahuannya sendiri melalui interaksinya dengan objek, fenomena, pengalaman, serta lingkungan mereka. Pengetahuan tidak dapat ditransfer begitu saja dari seseorang kepada orang lain, tetapi pengetahuan dibangun oleh orang yang belajar (Suparno, 1997: 28-29). Jadi, pengetahuan yang diperoleh oleh siswa bukan berasal dari guru yang memberikan pengetahuannya kepada siswa, melainkan siswa sendirilah yang membangun pemahamannya melalui interaksi dengan lingkungan-nya.

\section{Pembelajaran Inkuiri}

Menurut Webster's Collegiate Dictionary kata inkuiri (inquiry) berarti pertanyaan atau penyelidikan. Piaget memberikan definisi pendekatan inkuiri sebagai pendidikan yang mempersiapkan situasi bagi anak untuk melakukan eksperimen sendiri, mengajukan pertanyaan-pertanyaan dan mencari sendiri jawaban atas pertanyaan yang mereka ajukan.

Ada beberapa kelebihan dalam proses pembelajaran yang menggunakan metode inkuiri. Kelebihan metode inkuiri menurut Hanafiah dan Suhana ${ }^{6}$ yaitu (1) Peserta didik dapat mengembangkan penguasaan keterampilan dalam proses kognitif. (2) Peserta didik dapat memperoleh pengetahuan secara individual sehingga pengetahuan yang diperoleh dapat disimpan dalam pikirannya. (3) Metode inkuiri dapat memberikan kesempatan kepada peserta didik untuk mengembangkan minat dan kemampuan.

\section{Teori Belajar}

Teori belajar yang mendukung adalah teori belajar penemuan dan konstruktivisme. Teori belajar penemuan dari Bruner, belajar merupakan suatu proses aktif yang memungkinkan manusia untuk menemukan hal-hal baru diluar informasi yang diberikan kepada dirinya. Ada tiga proses

${ }^{6}$ Nanang Hanafiah, Cucu Suhana, Konsep Strategi Pembelajaran, (Surabaya: Refika Aditama, 2009), h. 79. 
kognitif yang terjadi dalam belajar yakni (1) proses perolehan informasi baru, (2) proses mentransformasikan informasi yang diterima,dan (3) menguji relevansi dan ketepatan pengetahuan.

Belajar matematika adalah belajar mengenai konsep-konsep dan struktur-struktur matematika yang terdapat di dalam materi yang dipelajari, serta mencari hubungan antara konsep-konsep dan struktur-struktur matematika itu. Ada 3 tahap dalam proses belajar menurut Bruner yaitu (1) Model Tahap Enaktif, dalam tahap ini penyajian yang dilakukan melalui tindakan peserta didik secara langsung terlibat dalam memanipulasi (mengotak-atik) objek. (2) Model Tahap Ikonik, dalam tahap ini kegiatan penyajian dilakukan berdasarkan pada pikiran internal dimana pengetahuan disajikan melalui serangkaian gambar-gambar atau grafik yang dilakukan peserta didik, berhubungan dengan mental yang merupakan gambaran dari objek-objek yang dimanipulasinya. (3) Model Tahap Simbolis, dalam tahap ini bahasa adalah pola dasar simbolik, peserta didik memanipulasi simbolsimbol atau lambang-lambang objek tertentu. Peserta didik tidak lagi terikat dengan objek-objek seperti pada tahap sebelumnya. Peserta didik pada tahap ini sudah mampu menggunakan notasi tanpa ketergantungan terhadap objek riil. Pada tahap simbolik ini, pembelajaran direpresentasikan dalam bentuk simbol-simbol abstrak yaitu simbol-simbol arbiter yang dipakai berdasarkan kesepakatan orang-orang dalam bidang yang bersangkutan, baik simbol-simbol verbal lambang-lambang matematika, maupun lambang-lambang abstrak yang lain.

\section{E. Pertumbuhan dan Perkembangan Anak}

Teori perkembangan intelektual Piaget, berpendapat bahwa proses berpikir manusia sebagai suatu perkembangan yang bertahap dari berpikir intelektual konkret ke abstrak berurutan melalui empat periode. Urutan periode itu tetap bagi setiap orang, namun usia atau kronologis pada setiap orang yang memasuki setiap periode berpikir yang lebih tinggi berbeda-beda tergantung kepada masing-masing individu. Ada empat tahap adalah sebagai berikut: (1) tahap sensori-motor (0-2 tahun); (2) tahap praoperasional (2-7 tahun); (3) tahap konkret operasional (7-12 tahun); (4) tahap formal operasional (12 dewasa).7 Siswa kelas I SD masuk dalam

${ }^{7}$ Muhsetyo, Gatot. Pembelajaran Matematika SD, (Jakarta: Universitas Terbuka, 2009). 
tahap pra-operasional yaitu suatu proses berpikir atau logik, dan merupakan aktivitas mental, bukan aktivitas sensori motor. Pada periode ini anak di dalam berpikirnya tidak didasarkan kepada keputusan yang logis melainkan didasarkan kepada keputusan yang dapat dilihat seketika. Pada tahap ini, anak mengalami masa-masa puncak pembelajaran. Kemampuan mengingat, menalar, dan merasakan perbedaan sikap atauperlakuan orang lain juga berkembang dengan pesat. Anak lebih sensitif, cerdas, dan aktif secara fisik amupun psikologis. Yang diperlukan pada masa-masa ini adalah pembelajaran yang bersifat keseimbangan menyeluruh secara terus menerus dan terpadu. Antara intelektual dengan emosional, moral dengan nalar, fisik dengan psikologis, teori dengan praktik, dan seterusnya.

Penerapan teori belajar Bruner pada perkalian bilangan bulat adalah:

1. Tahap Enaktif. Tahap ini anak disuruh membuat perkalian pecahan pada selembar kertas HVS, pecahan pertama dan kedua dituangkan pada HVS yang tersedia. Dengan ketrampilan melipat-lipat dibagi sesuai dengan menyebutnya maka jadilah Hasil perkalian dua pecahan. Setelah anak didik terbiasa dengan menggunakan media konkretnya HVS, baru dituangkan perkalian dua pecahan pada kertas berpetak.

2. Tahap Ikonik. Perkalian dua pecahan dituangkan dalam bentuk kertas berpetak maka ditentukan bahwa garis horisontal sebagai bilangan pertama atau pecahan pertama, garis vertikal sebagai bilangan kedua atau pecahan kedua. Bilangan pertama diberi warna yang berbeda dengan bilangan kedua. Daerah yang mendapatkan dua warna atau lebih maka itulah hasil perkalian dua pecahan.

3. Tahap Simbolik. Tahap ini menggunakan angka secara langsung utnuk menyimbolkan hasil dari perkalian dua bilangan.

\section{F. Konsep dan Pengertian}

Makna pecahan umumnya diartikan sebagai bagian yang ditentukan dari keseluruhan yang berukuran sama. Misalnya, dalam satu kantong terdapat 3 kelereng merah diantara 5 kelereng yang ada. Tentu dapat dipahami bahwa keseluruhan kelereng yang ada berukuran sama sebanyak 5 . Sebanyak 3 kelereng merah yang ditentukan diantara 5 kelereng yang ada merupakan sebuah pecahan, yakni 3 diantara 5 . 
Secara formal, makna pecahan sebagaimana diuraikan di atas dapat dinyatakan sebagai lambang bilangan. Andaikan sebanyak $\boldsymbol{a}$ di antara $\boldsymbol{b}$ keseluruhan yang berukuran sama maka lambang bilangan pecahan yang bersesuaian dapat dituliskan $\frac{\boldsymbol{a}}{\boldsymbol{b}}$ dimana $\boldsymbol{a}$ dan $\boldsymbol{b}$ merupakan bilangan bulat dengan $\boldsymbol{b}$ tidak sama dengan nol dan $\boldsymbol{b}$ bukan faktor dari $\boldsymbol{a}$. Dalam pecahan $\frac{a}{b}$, $a$ disebut sebagai pembilang dan $b$ disebut sebagai penyebut. Jadi, bagian kelereng merah sebanyak 3 diantara keseluruhan kelereng sebanyak 5 dapat dinyatakan dengan lambang bilangan pecahan, yaitu $\frac{3}{5}$.

Dapat dipahami bahwa $\frac{4}{2}$ dan $\frac{3}{1}$ bukan merupakan pecahan karena 2 adalah faktor dari 4 dan 1 adalah faktor dari 3. $\frac{4}{2}$ dan $\frac{3}{1}$ hanya sebagai bilangan rasional, yaitu bilangan yang dapat dinyatakan sebagai $\frac{\boldsymbol{a}}{\boldsymbol{b}}$ dimana $\boldsymbol{a}$ dan $\boldsymbol{b}$ merupakan bilangan bulat dengan $\boldsymbol{b}$ tidak sama dengan nol.

Secara umum pecahan dapat dinyatakan sebagai (1) pecahan sederhana, (2) pecahan campuran, (3) pecahan desimal dan (4) pecahan persen. Beberapa pengetahuan berkaitan pecahan yang penting dipelajari adalah:

(a) Menyatakan pecahan.

(b) Pecahan senilai.

(c) Mengubah pecahan campuran menjadi pecahan sederhana.

(d) Mengubah pecahan sederhana menjadi menjadi pecahan desimal dan pecahan persen.

(e) Mengoperasikan pecahan (penjumlahan, pengurangan, perkalian, dan pembagian). ${ }^{8}$

\section{G. Pecahan dalam Kehidupan Sehari-Hari}

Makna dan penggunaan Pecahan sering dijumpai dalam aktivitas anak sehari-hari, antara lain:

1. Ketika anak sakit demam, ibu memberikan obat dengan takaran separuh sendok makan. Separuh sendok makan mengindikasikan pecahan $\frac{1}{2}$.

2. Ketika upacara bendera, anak akan melihat bendera negara Indonesia (yaitu bendera merah putih) dengan warna merah sebanyak satu per dua

8 Bahan ajar Pembelajaran Matematika SD/MI, USAID. 
dan warna putih juga satu per dua. Bagian warna merah dituliskan $\frac{\mathbf{1}}{\mathbf{2}}$ atau bagian warna putih juga dituliskan $\frac{1}{2}$.

3. Dalam operasi hitung pecahan, seseorang petani di desa mempunyai kebiasaan setelah panen tebu, dia akan membagikan gula kepada tetangganya. Dia akan membagikan gula sebanyak $30 \mathrm{~kg}$ dan untuk tiap tetangga akan diberikan $\frac{1}{2} \mathrm{~kg}$ dalam 1 kantong plastik. Banyaknya kantong plastik yang perlu disediakan oleh petani tersebut adalah 60 lembar.

Satu permasalahan penting yang perlu didiskusikan adalah apakah 1 kepingan tertentu dari pecahan gelas yang pecah menjadi 5 kepingan berbeda dapat dinyatakan sebagai pecahan? Jawabannya, iya. Diskusikan bagaimana menyatakan 1 kepingan tertentu dari pecahan gelas tersebut sebagai suatu pecahan?

Pembelajaran konsep pecahan pada siswa sekolah dasar ada 2 macam yaitu benda konkret sebagai alat peraga penanaman konsep dan penggunaan benda-benda semi konkret dalam menerangkan konsep pecahan. ${ }^{9}$

Skenario pembelajaran dan LK yang dipakai;

\section{SKENARIO PEMBELAJARAN}

A. Kegiatan Awal

1. Guru membuka memori siswa tentang menentukan hasil Kls $5^{\prime}$ perkalian dengan menggunakan kertas berpetak yang diberi sumbu cartesius.

2. Guru menjelaskan tujuan pembelajaran pada hari ini.

B. Kegiatan Inti

1. Siswa mengamati kertas berpetak yang sudah diberi sumbu cartesius. (Mengamati)

2. Siswa mengamati dan menghitung daerah yang diarsir dan daerah keseluruhan pada kertas berpetak tersebut, selanjutnya menuliskannya ke dalam bentuk pecahan. (Mengamati dan mengumpulkan informasi)

9Karso, Pendidikan Matematika I, (Jakarta: Universitas Terbuka, 2008). 
3. Siswa menduga perkalian pecahan yang menunjukkan daerah arsiran didasarkan pada gambar. (Menanya)

4. Siswa membuktikan hasil dugaan perkalian pecahan yang $\begin{array}{lll}\text { menunjukkan daerah arsiran. (Mengolah informasi) } & \text { I/Ps } & 10^{\prime}\end{array}$

5. Siswa saling bertukar gagasan/hasil pembuktian dengan teman sebelah kanan atau kiri. (Mengkomunikasikan)

6. Siswa menyelesaikan permasalahan yang terdapat pada LK. 01. (Mengolah informasi)

7. Beberapa siswa diminta maju ke depan kelas untuk menunjukkan hasil kerja dalam penyelesaian masalah yang terdapat pada LK. 01. (Mengkomunikasikan)

C. Kegiatan Penutup

1. Penguatan

Guru memberi penguatan dengan memeriksa bersama siswa, pekerjaan mana saja yang hasilnya sudah benar dan belum benar.

2. Refleksi

- Kemampuan apa saja yang sudah dikuasai

- Hal apa saja yang masih membingungkan

- Perasaan yang dirasakan siswa ketika belajar

\section{Lembar Kerja 01.}

\section{PERKALIAN PECAHAN BIASA DENGAN PECAHAN BIASA}
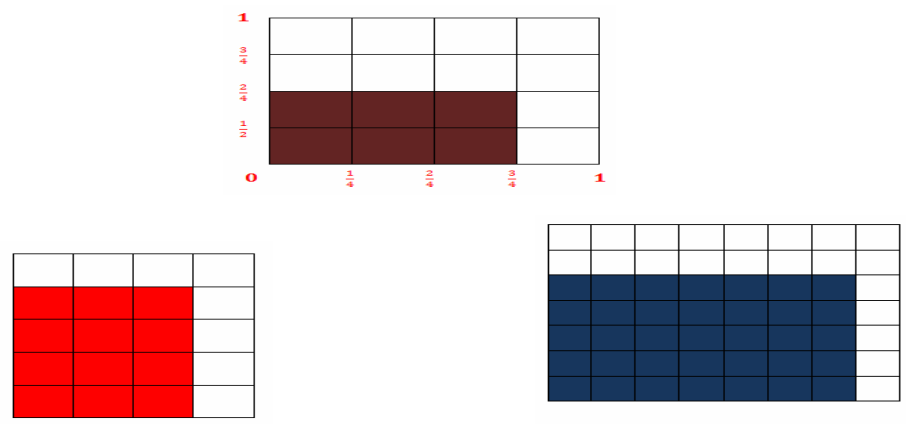

Gambar 1

Gambar $\mathbf{z}$

Gambar di atas memperlihatkan ... daerah yang diarsir dari ... daerah keseluruhan yang menunjukkan ...

Perkalian yang ditunjukkan gambar tersebut adalah ... 
Permasalahan

1. Dapatkah Kalian menunjukkan perkalian pecahan pada Gambar 1 dan hasil perkalian pecahannya?

2. Dapatkah Kalian menunjukkan perkalian pecahan pada Gambar 2 dan hasil perkalian pecahannya?

3. Bagaimana Kalian menunjukkan daerah arsiran perkalian pecahan $\frac{3}{5} \times \frac{4}{9}$ ?

4. Bagaimana menunjukkan hasil perkalian dari dua pecahan berbeda yang Kalian tentukan sendiri?

Lembar kerja siswa lain yang digunakan

\section{PERKALIAN PECAHAN}

Bagaimana menentukan hasil perkalian dua pecahan berikut ini?

$$
\frac{2}{3} \times \frac{3}{4}
$$

Ikuti dan lakukan langkah-langkah berikut ini

1. Buat sumbu Cartesius

2. Buat skala satuan pada kedua sumbunya

3. Skala satuan pada sumbu horizontal bagi menjadi 3 bagian yang sama

4. Skala satuan pada sumbu vertikal bagi menjadi 4 bagian yang sama

5. Buat garis vertikal melalui skala $\frac{2}{3}$; pada sumbu horizontal

6. Buat garis horizontal melalui skala ${ }^{\frac{3}{4}}$ pada sumbu vertikal 
7. Daerah yang dibatasi kedua garis tersểbut dan kedua sumbu koordinat merupakan daerah hasil perkalian ${ }^{\frac{3}{3}}{ }^{-}$yang dicari, yakni 6 bagian dari 12 area keseluruhan

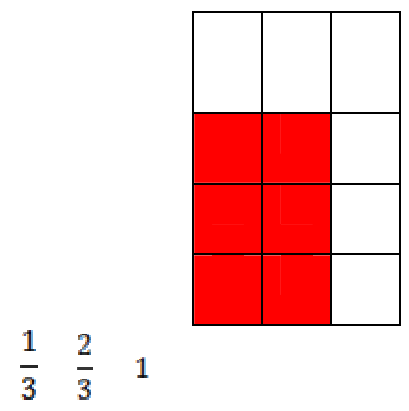

Jadi,

$$
\frac{2}{3} \times \frac{3}{4}=\frac{6}{12}
$$

Pertanyaan dan tugas!

Gunakan langkah-langkah perkalian pecahan di atas untuk menentukan hasil perkalian berikut ini.
(1) $\frac{1}{5} \times \frac{2}{3}$
(2) $\frac{1}{4} \times \frac{3}{5}$
(3) $\frac{2}{7} \times \frac{1}{3}$

\section{Media Benda konkret yang Digunakan}

Media benda konkret yang digunakan untuk menjelaskan konsep perkalian pecahan biasa:

1. Sediakan selembar kertas HVS kosong.

2. Sediakan 2 spidol warna yang berbeda atau pensil warna yang berbeda.

3. Jika soalnya $\frac{3}{4} x \frac{2}{3}$ maka tentukan dulu mana yang sebagai sumbu horison bilangan pertama dan bilangan kedua sebagai sumbu vertikal. 
4. Karena sumbu horison adalah $\frac{3}{4}$ maka kertas HVS dilipat menjadi 4 bagian yang sama besar. Setiap lipatan diberi garis lurus, sehingga ada 4 bagian. 3 bagian di arsir menggunakan spidol yang sama.

5. Karena sumbu vertikal adalah ${ }^{\frac{2}{3}}$ maka kertas HVS yang diarsir tadi kita gunakan untuk menggambar bagian untuk sumbu vertikal. Sumbu vertikal dibagi 3 bagian. Setiap lipatan diberi gari lurus dengan spidol yang berbeda, sehingga ada 3 bagian. 2 bagian diarsir dengan spidol yang sama.

6. Didalam kertas HVS ada kotak yang berwarna dua yaitu hitam dan merah. Jadi hasil dari perkalian terlihat dari kotak yang diarsir dengan dua warna. Ada 6 bagian yang diarsir dengan 2 warna dan semua kotak yang diarsir maupun yang tidak ada 12. Sehingga $\frac{3}{4} \times \frac{2}{3}=\frac{6}{12}$

\section{H. Konsep Gender}

Menurut Fazlurrachman istilah gender diketengahkan oleh para ilmuwan sosial untuk menjelaskan mana perbedaan perempuan dan laki-laki yang bersifat bawaan sebagai ciptaan Tuhan dan mana yang merupakan bentukan budaya yang dikonstruksikan, dipelajari dan disosialisasikan. ${ }^{10}$ Pembedaan ini sangat penting karena selama ini kita seringkali mencampuradukkan ciri manusia yang bersifat kodrati dan tidak berubah, dengan ciri manusia yang bersifat nonkodrati yang sebenarnya dapat berubah atau diubah. Dengan kata lain masyarakat tidak membedakan yang mana sebetulnya jenis kelamin (kodrat) dan yang mana gender.

Menurut Yusuf dalam makalahnya yang berjudul "Perbandingan Gender dalam Prestasi Literasi Siswa Indonesia" menyebutkan bahwa siswa perempuan mendapatkan kenaikan nilai yang lebih tinggi dibandingkan dengan siswa laki-laki dengan perbedaan nilai sebesar 16 poin

\footnotetext{
${ }^{10}$ Haris Fazlurrachman, Monograf Bahan Ajar Gender, dalam http://curhatpendidikan. blogspot.com/2008/07/monograf.html. (6-1-2009)
} 
untuk siswa perempuan dan 11 poin untuk siswa laki-laki. ${ }^{11}$ Pencapaian untuk masing-masing tingkat literasi menunjukkan bahwa pencapaian siswa perempuan di bawah tingkat literasi- 1 bertambah dengan drastis dengan penurunan pencapaian pada tingkat literasi-3 sampai 5. Keadaan kemampuan siswa perempuan yang lebih baik pada tingkat literasi-1 dan 2, sedangkan kemampuan siswa laki-laki menumpuk pada tingkat literasi-1 ke bawah.

Pada literasi matematika, pencapaian siswa laki-laki masih lebih tinggi dibandingkan dengan siswa perempuan pada hampir semua negara peserta yang diteliti PISA. Kemampuan matematika antara siswa laki-laki dengan perempuan di Indonesia menurut data Pisa 2006 menunjukkan bahwa ratarata kemampuan matematika siswa laki-laki lebih tinggi 17 poin daripada siswa perempuan. Dimana rata-rata kemampuan siswa laki-laki mencapai skor 399, dan siswa perempuan mencapai skor 382.

\section{Pembahasan Penerapan Perkalian Operasi Perkalian pada Pecahan di Kelas 5 SDN Sambiroto 3}

Pelajaran matematika di sekolah dasar adalah mempelajari setiap konsep secara bertahap untuk mendapatkan pengertian, hubunganhubungan, simbol-simbol, kemudian mengaplikasikan konsep-konsep ke situasi yang baru. Matematika adalah suatu pelajaran yang tersusun secara berurutan, berjenjang dari yang paling mudah sampai ke tingkat yang paling rumit. Matematika di sekolah dasar sangatlah penting, sebab konsep dasar matematika inilah yang akan dii ajarkan di bangku sekolah dasar. Jika di sekolah dasar sudah mengalami miskonsepsi terhadap suatu konsep dasar dalam matematika, sampai dewasapun dia akan ingatnya apa yang telah disampaikan ibu guru atau bapak guru sejak di bangku sekolah dasar. Guruguru lebih suka memberikan sebuah ilmu yang instan saja. Ilmu yang instan akan cepat hilang dibandingkan ilmu yang memalui proses pembelajaran, misalnya pembelajaran dengan pendekatan inkuiri, pembelajaran dengan bantuan alat-alat peraga murah dilingkungan sekitar.

\footnotetext{
${ }^{11}$ Yusuf, Suhendra. Perbandingan Gender dalam Prestasi Literasi Siswa Indonesia. Dalam http://www.uninus.ac.id/PDF/Suhendra\%20Yusuf\%20\%20Makalah\%20untuk\%20Jurnal\%20 Uninus.pdf. (20-12-2008).
} 
Penanaman konsep perkalian pada pecahan di sekolah dasar kelas 5 dengan beberapa cara, bukan dengan cara instan. Contoh instan disini adalah pokoknya kalau ada perkalian pecahan maka hasilnya adalah pembilang dikali pembilang per penyebut dikalikan penyebut, tanpa anak tahu proses dimana terjadinya hasil seperti itu. Jawaban itu benar tetapi anak tidak tahu darimana hasil itu didapat, tanpa diberitahu langkahnya untuk mendapatkan itu. Terakhir jawab itu sama, tetapi didalam pembelajaran perkalian pecahan disini, akan memperlihatakan proses terjadinya hasil kali dua pecahan.

Dua cara pendekatan yang dilakukan untuk mendapatkan perkalian dua pecahan yaitu: 1) Media benda konkret; 2) Gambar pada kertas berpetak.

Menurut teori Bruner dimana ada tiga tahapan yaitu tahap enaktif, tahap ikonik dan tahap simbolik. (1) Model Tahap Enaktif, dalam tahap ini penyajian yang dilakukan melalui tindakan peserta didik secara langsung terlibat dalam memanipulasi (mengotak-atik) objek. (2) Model Tahap Ikonik, dalam tahap ini kegiatan penyajian dilakukan berdasarkan pada pikiran internal dimana pengetahuan disajikan melalui serangkaian gambargambar atau grafik yang dilakukan peserta didik, berhubungan dengan mental yang merupakan gambaran dari objek-objek yang dimanipulasinya. (3) Model Tahap Simbolis, dalam tahap ini bahasa adalah pola dasar simbolik, peserta didik memanipulasi simbol-simbol atau lambang-lambang objek tertentu. Media benda konkret yang digunakan ini masuk pada tahap enaktif, dimana peserta didik atau siswa menggunakan alat bantua tau media bantu. Media benda konkret yang dipakai adalah potongan kertas lipat, atau potongan kertas HVS. Dengan mempraktikan menggunakan potongan kertas HVS siswa kelas 5 SDN Sambiroto sangat antusias, sangat aktif, rasa ingin tahunya siswa kelas 5 ini sangat luar biasa, dilihat dari keaktifan anak dikelas semua anak aktif mau mencoba, tidak ada satupun anak yang melewati kegiatan ini dengan berdiam diri. Semua anak mencoba dengan instruksi dari gurunya. Saat pertama sebagian anak lakilaki masih bingung, dimana anak perempuan sudah paham semua. Untuk contoh keduanya, ternyata anak laki-laki semuanya cepat menyelesaikan tugasnya dengan baik. Pada soal yang ketiga dengan gesit, cepat anak anak kelas 5 dapat menyelasikan soal yang diberikan guru dengan sempurna. Kegiatan yang dilakukan dalam pembelajaran perkalian pecahan, dapat 
meningkatkan hasil pemahaman anak perempuan dan anak laki-laki. Kemampuan anak laki-laki dan perempuan tidak ada perbedaan. Hasil evaluasi yang didapat rata-rata anak laki-laki dan perempuan sama. Ada kecenderungan anak perempuan lebih cepat menguasi dibandingkan anak laki-laki saat dilakukan proses pembelajaran.

\section{J. Kesimpulan}

Pembelajaran perkalian dua pecahan emang sangatlah penting dalam menerapkan konsep dasar perkalian yaitu dengan bantuan benda konkret dan kertas berpetak. Dimana dalam pembelajaran itu juga menggunakan teori belajaran Bruner, serta menggunakan pendekatan inkuiri. Setelah di terapkan dalam pada anak kelas 5 di SDN Sambiroto Tembalang Semarang dapat meningkatkan hasil pemahaman anak perempuan dan anak laki-laki terhadap perkalian pecahan. Kemampuan anak laki-laki dan perempuan tidak ada perbedaan. Hasil evaluasi sama, saat proses berbeda ada kecenderungan anak perempuan lebih cepat menguasi dibandingkan anak laki-laki.]

\section{Daftar Pustaka}

Bachtiar Soeseno, Buku Pintar memahami Psikologi Anak Didik, (Yogjakarta: Pinang Merah Publisher, 2012)

Fazlurrachman, Haris, 2008, Monograf Bahan Ajar Gender. http:// curhatpendidikan.blogspot.com/2008/07/monograf. html. (6-1-2009)

Karim, Abdul Muchtar, dkk, Pendidikan Matematika 2, (Jakarta: Universitas Terbuka, 2014)

Karso, dkk. , Pendidikan Matematika 1, Jakarta: Universitas Terbuka, 2014.

Muhsetyo, Gatot, Pembelajaran Matematika SD, Jakarta: Universitas Terbuka, 2009.

Yusuf, Suhendra. Perbandingan Gender dalam Prestasi Literasi Siswa Indonesia. http://www.uninus.ac.id/PDF/Suhendra\%20Yusuf\%20\%20Makalah\%20u ntuk\%20Jurnal\%20Uninus. pdf. (20-12-2008).

Tim Penyusun, Pembelajaran Matematika Sekolah Dasar di LPTK, (Jakarta: USAID PRIORITAS, 2015. 
